\section{Ligand Control on Molecular Oxygen Activation by Rhodium Quinone Complexes}

\section{Swati Dutta, ${ }^{\dagger}$ Shie-Ming Peng, ${ }^{\ddagger}$ and Samaresh Bhattacharya ${ }^{*, \dagger}$}

Department of Chemistry, Inorganic Chemistry Section, Jadavpur University, Calcutta 700032, India, and Department of Chemistry, National Taiwan University, Taipei, Taiwan, ROC

Received August 18, 1999

\section{Introduction}

Activation of molecular oxygen has been an attractive area of chemical research ${ }^{1-11}$ with reference to utilization of the cheapest oxidant for bringing about useful redox transformations. Synthesis of transition metal complexes with potential ability to interact with molecular oxygen has thus been of significant importance. Herein we wish to disclose some interesting results of our studies in this area involving quinone complexes of rhodium. Rhodium offers two stable oxidation states, viz. +1 and +3 , while the intermediate +2 state is very unstable. ${ }^{12}$ In the present work we have studied the reaction between rhodium(I) and 1,2-benzoquinones. 1,2-Benzoquinones (BQ) are known to undergo two successive one-electron reductions (eq 1)

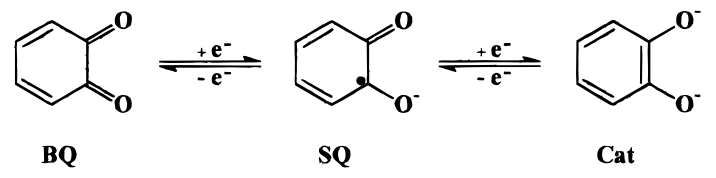

producing respectively the semiquinone radical anion (SQ) and the catecholate ion (Cat). ${ }^{13}$ Similarly rhodium(I) is capable of undergoing two one-electron oxidations to afford respectively rhodium(II) and rhodium(III). Hence reaction of the quinones with rhodium(I) may result in either a reactive $\mathrm{Rh}^{\mathrm{II}}-\mathrm{SQ}$ intermediate or a stable $\mathrm{Rh}^{\mathrm{III}}-\mathrm{Cat}$ complex. The fate of such redox reaction is expected to be dictated solely by the quinone ligand. Quinones with strong oxidizing power are likely to end up giving stable $\mathrm{Rh}^{\mathrm{III}}-$ Cat complexes, whereas quinones that are weaker oxidants may reach only up to the $\mathrm{Rh}^{\mathrm{II}}-\mathrm{SQ}$ stage. $\mathrm{The} \mathrm{Rh}^{\mathrm{II}}-\mathrm{SQ}$ complexes are expected to be susceptible to attack by molecular oxygen, provided the metal is approachable by dioxygen in these $\mathrm{Rh}^{\mathrm{II}}-\mathrm{SQ}$ complexes, and thus they may

\footnotetext{
$\dagger$ Jadavpur University.

$\div$ National Taiwan University.

(1) Chem. Rev. 1994, 94.

(2) Oxygen Metabolism. Chem. Rev. 1996, 96, pp 2541-2927.

(3) Tollman, W. Acc. Chem. Res. 1997, 30, 227.

(4) Hamstra, B. J.; Colpas, G. J.; Pecoraro, V. L. Inorg. Chem. 1998, 37, 949.

(5) Liu, X. Y.; Palacios, A. A.; Novoa, J. J.; Alvarez, S. Inorg. Chem. 1998, 37, 1202.

(6) Zauche, T. H.; Espenson, J. H. Inorg. Chem. 1998, 37, 6827.

(7) Butler, A. Coord. Chem. Rev. 1999, 187, 17

(8) Kachadourian, R.; Batiuilc-Haberle, I.; Fridovich, I. Inorg. Chem. 1999, $38,391$.

(9) McGrady, J. E.; Stranger, R. Inorg. Chem. 1999, 38, 550.

(10) Tetzlaff, H. R.; Espenson, J. H. Inorg. Chem. 1999, 38, 881.

(11) Thapper, A.; Death, R. J.; Norlander, E. Inorg. Chem. 1999, 38, 1015

(12) Comprehensive Coordination Chemistry; Pergamon Press: New York, 1987; Vol. 4, p 930.

(13) Pierpont, C. G.; Buchanan, R. M. Coord. Chem. Rev. 1981, 38, 45
}

activate molecular oxygen. We have tested this hypothesis using Wilkinson's catalyst, $\left[\mathrm{Rh}\left(\mathrm{PPh}_{3}\right)_{3} \mathrm{Cl}\right]$, as the source of rhodium(I) and two symmetric orthoquinones with significant difference in their oxidizing capacities, viz. 9,10-phenanthrenequinone $(\mathrm{PBQ}, \mathbf{1})$ and 3,4,5,6-tetrachloro-1,2-benzoquinone $\left(\mathrm{Cl}_{4} \mathrm{BQ}, 2\right)$.<smiles>O=C1C(=O)c2ccccc2-c2ccccc21</smiles>

1<smiles>O=C1C(=O)C(Cl)=C(Cl)C(Cl)=C1Cl</smiles>

2
9,10-Phenanthrenequinone shows the two reductions at -0.70 and $-1.21 \mathrm{~V}$ vs SCE, while 3,4,5,6-tetrachloro-1,2-benzoquinone undergoes two similar reductions at 0.08 and $-0.59 \mathrm{~V}$ vs SCE. ${ }^{14}$ Wilkinson's catalyst has been chosen as the source of rhodium because this tetracoordinated $\left[\mathrm{Rh}\left(\mathrm{PPh}_{3}\right)_{3} \mathrm{Cl}\right]$ complex is known to release one $\mathrm{PPh}_{3}$ in solution ${ }^{15}$ and thus it offers three available coordination sites of the metal, two of which may be occupied by the quinone ligand leaving the pentacoordinated rhodium approachable by a monodentate ligand. Reaction of the above two quinones with $\left[\mathrm{Rh}\left(\mathrm{PPh}_{3}\right)_{3} \mathrm{Cl}\right]$ indeed afforded two different complexes with remarkably different properties, and a brief account of this chemistry is described here.

\section{Experimental Section}

Materials. Rhodium trichloride was obtained from Johnson Matthey, and triphenylphosphine was purchased from Loba, Mumbai, India. [Rh$\left(\mathrm{PPh}_{3}\right)_{3} \mathrm{Cl}$ ] was synthesized by following a reported procedure. ${ }^{16} 3,4,5,6$ Tetrachloro-1,2-benzoquinone was purchased from Aldrich, and 9,10phenanthrenequinone was purchased from Merck, Mumbai, India. Purification of dichloromethane and acetonitrile and preparation of tetrabutylammonium perchlorate (TBAP) for electrochemical work were performed as before. ${ }^{17,18}$

Preparation of [ $\mathbf{R h}\left(\mathbf{P P h}_{\mathbf{3}}\right)_{\mathbf{2}}\left(\mathbf{O}_{\mathbf{2}}\right.$-PSQ)Cl]. 9, 10-Phenanthrenequinone (23 $\mathrm{mg}, 0.11 \mathrm{mmol}$ ) was dissolved in dry benzene $\left(40 \mathrm{~cm}^{3}\right)$, and to it was added $\left[\mathrm{Rh}\left(\mathrm{PPh}_{3}\right)_{3} \mathrm{Cl}\right](100 \mathrm{mg}, 0.11 \mathrm{mmol})$. The mixture was then stirred for $4 \mathrm{~h}$ to produce a red solution. On partial evaporation of the solution $\left[\mathrm{Rh}\left(\mathrm{PPh}_{3}\right)_{2}\left(\mathrm{O}_{2}\right.\right.$-PSQ $\left.) \mathrm{Cl}\right]$ separated as a reddish-orange crystalline solid, which was then collected by filtration, washed thoroughly with hexane, and dried in air. Yield: $75 \%$. Anal. Calcd for $\mathrm{C}_{50} \mathrm{H}_{38} \mathrm{O}_{4}$ $\mathrm{ClP}_{2} \mathrm{Rh}$ : C, 66.50; H, 4.21. Found: C, 66.56; H, 4.25.

Preparation of $\left[\mathbf{R h}\left(\mathbf{P P h}_{\mathbf{3}}\right)_{\mathbf{2}}\left(\mathbf{C l}_{\mathbf{4}} \mathbf{C a t}\right) \mathbf{C l}\right]$. This was prepared by following the same above procedure using 3,4,5,6-tetrachloro-1,2benzoquinone instead of 9,10-phenanthrenequinone. Yield: $70 \%$. Anal. Calcd for $\mathrm{C}_{42} \mathrm{H}_{30} \mathrm{O}_{2} \mathrm{Cl}_{5} \mathrm{P}_{2} \mathrm{Rh}$ : C, 55.48; H, 3.30. Found: C, 55.47; $\mathrm{H}$, 3.31.

Peparation of $\left[\mathbf{R h}\left(\mathbf{P P h}_{3}\right)_{2}\left(\mathbf{C l}_{\mathbf{4}} \mathbf{C a t}\right)\left(\mathbf{C H}_{3} \mathbf{C N}\right) \mathbf{C l}\right]$. [Rh $\left(\mathrm{PPh}_{3}\right)_{2}\left(\mathrm{Cl}_{4}\right.$ Cat)Cl] (50 mg, $0.05 \mathrm{mmol})$ was dissolved in acetonitrile. Partial evaporation of the solvent afforded $\left[\mathrm{Rh}\left(\mathrm{PPh}_{3}\right)_{2}\left(\mathrm{Cl}_{4} \mathrm{Cat}\right)\left(\mathrm{CH}_{3} \mathrm{CN}\right) \mathrm{Cl}\right]$ as a violet crystalline solid, which was collected by decanting the excess solvent and dried in vacuo. Yield: $80 \%$. Anal. Calcd for $\mathrm{C}_{44} \mathrm{H}_{33} \mathrm{O}_{2}$ $\mathrm{Cl}_{5} \mathrm{P}_{2} \mathrm{NRh}$ : C, 55.61; H, 3.48; N, 1.47. Found: C, 55.62; H, 3.47; N, 1.48 .

(14) Potentials obtained from cyclic voltametry carried out by us.

(15) Cotton, F. A.; Wilkinson, G. Advanced Inorganic Chemistry; Wiley Eastern: New Delhi, 1985; p 788.

(16) Osborn, J. A.; Wilkinson, G. Inorg. Synth. 1967, 10, 67.

(17) Sawyer, D. T.; Roberts, J. L., Jr. Experimental Electrochemistry for Chemists; Wiley: New York, 1974; pp 167-215.

(18) Walter, M.; Ramaley, L. Anal. Chem. 1973, 45, 165 
Table 1. Crystallographic Data for $\left[\mathrm{Rh}\left(\mathrm{PPh}_{3}\right)_{2}\left(\mathrm{O}_{2}-\mathrm{PSQ}\right) \mathrm{Cl}\right] \cdot \mathrm{C}_{6} \mathrm{H}_{6}$ and $\left[\mathrm{Rh}\left(\mathrm{PPh}_{3}\right)_{2}\left(\mathrm{Cl}_{4} \mathrm{Cat}\right)\left(\mathrm{CH}_{3} \mathrm{CN}\right) \mathrm{Cl}\right]$

\begin{tabular}{|c|c|c|}
\hline empirical formula & $\mathrm{C}_{56} \mathrm{H}_{44} \mathrm{ClO}_{4} \mathrm{P}_{2} \mathrm{Rh}$ & $\mathrm{C}_{44} \mathrm{H}_{33} \mathrm{Cl}_{5} \mathrm{NO}_{2} \mathrm{P}_{2} \mathrm{Rh}$ \\
\hline & 981.21 & 949.81 \\
\hline space group & monoclinic, $P 2_{1} / C$ & orthorhombic, $\mathrm{Pbca}$ \\
\hline$a, \AA$ & $10.5316(2)$ & $16.2358(7)$ \\
\hline$b, \AA$ & $19.9374(1)$ & $18.3175(7)$ \\
\hline$c, \AA$ & $22.4162(5)$ & $27.0680(8)$ \\
\hline$\alpha, \operatorname{deg}$ & 90 & 90 \\
\hline$\beta, \operatorname{deg}$ & $96.712(1)$ & 90 \\
\hline$\gamma, \operatorname{deg}$ & 90 & 90 \\
\hline$V, \AA^{3}$ & $4674.53(14)$ & $8050.0(5)$ \\
\hline$Z$ & 4 & 8 \\
\hline$\rho_{\text {calcd }}, \mathrm{g} \mathrm{cm}^{-3}$ & 1.394 & 1.567 \\
\hline$\rho_{\text {obsd }}, \mathrm{g} \mathrm{cm}^{-3}$ & 1.397 & 1.565 \\
\hline$\lambda, \AA$ & 0.71073 & 0.71073 \\
\hline cryst size, $\mathrm{mm}$ & $0.40 \times 0.10 \times 0.10$ & $0.20 \times 0.04 \times 0.02$ \\
\hline$T,{ }^{\circ} \mathrm{C}$ & 22 & 22 \\
\hline$\mu, \mathrm{mm}^{-1}$ & 0.538 & 0.876 \\
\hline $\mathrm{R} 1^{a}$ & 0.0767 & 0.1146 \\
\hline $\mathrm{wR} 2^{b}$ & 0.1317 & 0.1246 \\
\hline GOF on $F^{2 c}$ & 1.024 & 1.379 \\
\hline
\end{tabular}

${ }^{a} \mathrm{R} 1=\sum|| F_{\mathrm{o}}|-| F_{\mathrm{c}}|| / \sum\left|F_{\mathrm{o}}\right|{ }^{b} \mathrm{wR} 2=\left[\sum\left[w\left(F_{\mathrm{o}}{ }^{2}-F_{\mathrm{c}}{ }^{2}\right)^{2}\right] / \sum\left[w\left(F_{\mathrm{o}}{ }^{2}\right)^{2}\right]\right]^{1 / 2}$. ${ }^{c} \mathrm{GOF}=\left[\sum\left[w\left(F_{\mathrm{o}}{ }^{2}-F_{\mathrm{c}}{ }^{2}\right)^{2}\right] /(M-N)\right]^{1 / 2}$, where $M$ is the number of reflections and $N$ is the number of parameters refined.

Physical Measurements. Microanalyses $(\mathrm{C}, \mathrm{H}, \mathrm{N})$ were performed using a Perkin-Elmer 240C elemental analyzer. IR spectra were obtained on a Perkin-Elmer 783 spectrometer with samples prepared as $\mathrm{KBr}$ pellets. Electronic spectra were recorded on a Shimadzu UV-1601 spectrophotometer. Magnetic susceptibilities were measured using a PAR 155 vibrating-sample magnetometer. ${ }^{1} \mathrm{H}$ and ${ }^{31} \mathrm{P}$ NMR spectra were obtained on a Brucker drx500 NMR spectrometer using TMS as the internal standard. Solid-state thermal investigations were carried out with the help of a Shimadzu DT-30 thermal analyzer. Electrochemical measurements were made using a PAR model 273 potentiostat. A platinum-disk working electrode, a platinum wire auxiliary electrode, and an aqueous saturated calomel reference electrode (SCE) were used in a three-electrode configuration. A RE $0089 \mathrm{X}-\mathrm{Y}$ recorder was used to trace the voltammograms. Electrochemical measurements were made under a dinitrogen atmosphere. All electrochemical data were collected at $298 \mathrm{~K}$ and are uncorrected for junction potentials.

Crystallography of $\left[\mathbf{R h}\left(\mathbf{P P h}_{3}\right)_{2}\left(\mathbf{O}_{2}-\mathrm{PSQ}\right) \mathbf{C l}\right] \cdot \mathbf{C}_{6} \mathbf{H}_{6}$. Single crystals were grown by slow evaporation of a benzene solution of the complex. Selected crystal data and data collection parameters are given in Table 1. Data were collected on a SMART CCD diffractometer using graphitemonochromated Mo $\mathrm{K} \alpha$ radiation $(\lambda=0.71073 \AA)$ by $\omega$ scans. X-ray data reduction, structure solution, and refinement were done using the SHELXTL-PLUS package. The structure was solved by direct methods.

Crystallography of $\left[\mathrm{Rh}\left(\mathrm{PPh}_{3}\right)_{2}\left(\mathrm{Cl}_{4} \mathrm{Cat}\right)\left(\mathrm{CH}_{3} \mathrm{CN}\right) \mathrm{Cl}\right]$. Single crystals were grown by slow evaporation of an acetonitrile solution of [Rh$\left.\left(\mathrm{PPh}_{3}\right)\left(\mathrm{Cl}_{4} \mathrm{Cat}\right)\left(\mathrm{CH}_{3} \mathrm{CN}\right) \mathrm{Cl}\right]$. Selected crystal data and data collection parameters are given in Table 1. Data collection and structure solution and refinement were done similarly as above.

\section{Results and Discussion}

Reaction of 9,10-phenanthrenequinone with $\left[\mathrm{Rh}\left(\mathrm{PPh}_{3}\right)_{3} \mathrm{Cl}\right]$ at ambient temperature afforded the $\left[\mathrm{Rh}\left(\mathrm{PPh}_{3}\right)_{2}\left(\mathrm{O}_{2}-\mathrm{PSQ}\right) \mathrm{Cl}\right] \mathrm{com}-$ plex whose identity has been revealed by its molecular structure determination by X-ray crystallography. A view of the complex molecule is shown in Figure 1, and selected bond parameters are listed in Table 2. The quinone ligand has undergone interesting chemical transformation. One oxygen molecule has been occluded in this complex which is present in the peroxo form bridging the metal and the tetrahedral carbon of the quinone ligand. The two $\mathrm{PPh}_{3}$ ligands have occupied cis positions. The $\mathrm{O}_{3} \mathrm{P}_{2} \mathrm{Cl}$ coordination sphere around rhodium is significantly distorted from ideal octahedral geometry, which is reflected in the bond parameters, particularly in the $\mathrm{O}(2)-$ $\mathrm{Rh}-\mathrm{P}(2), \mathrm{O}(1)-\mathrm{Rh}-\mathrm{P}(1)$, and $\mathrm{O}(3)-\mathrm{Rh}-\mathrm{Cl}$ bond angles.

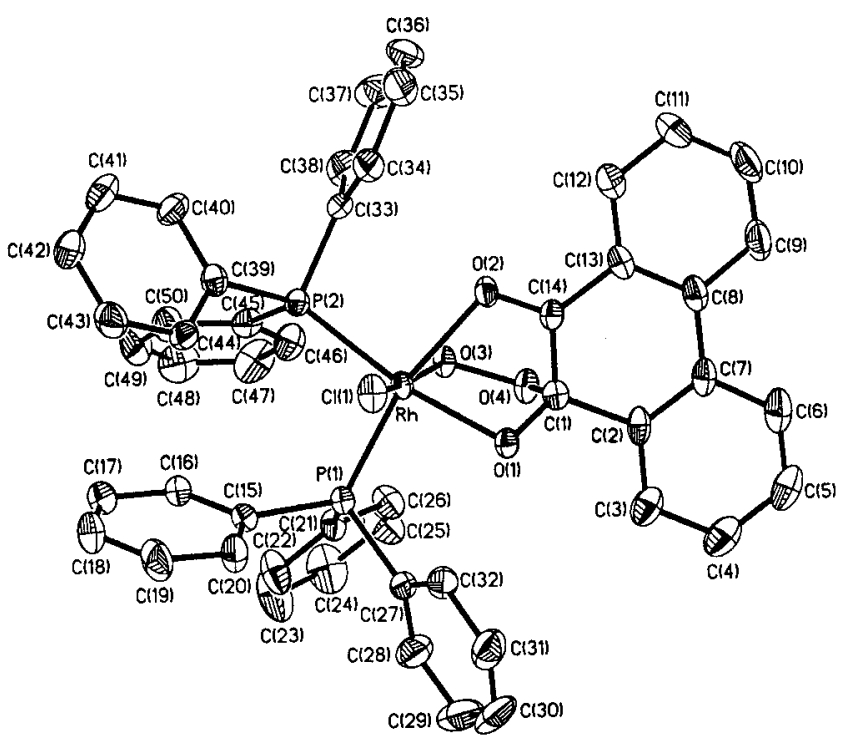

Figure 1. View of the $\left[\mathrm{Rh}\left(\mathrm{PPh}_{3}\right)_{2}\left(\mathrm{O}_{2}-\mathrm{PSQ}\right) \mathrm{Cl}\right]$ molecule.

Table 2. Selected Bond Distances and Bond Angles for $\left[\mathrm{Rh}\left(\mathrm{PPh}_{3}\right)_{2}\left(\mathrm{O}_{2}-\mathrm{PSQ}\right) \mathrm{Cl}\right] \cdot \mathrm{C}_{6} \mathrm{H}_{6}$ and $\left[\mathrm{Rh}\left(\mathrm{PPh}_{3}\right)_{2}\left(\mathrm{Cl}_{4} \mathrm{Cat}\right)\left(\mathrm{CH}_{3} \mathrm{CN}\right) \mathrm{Cl}\right]$

\begin{tabular}{lccc}
\multicolumn{5}{c}{$\left.\left[\mathrm{Rh}^{\mathrm{C}} \mathrm{PPh}_{3}\right)_{2}\left(\mathrm{O}_{2}-\mathrm{PSQ}\right) \mathrm{Cl}\right] \cdot \mathrm{C}_{6} \mathrm{H}_{6}$} \\
$\mathrm{Rh}-\mathrm{O}(1)$ & $2.015(4)$ & $\mathrm{C}(1)-\mathrm{O}(1)$ & $1.362(7)$ \\
$\mathrm{Rh}-\mathrm{O}(2)$ & $2.179(4)$ & $\mathrm{C}(1)-\mathrm{O}(4)$ & $1.472(7)$ \\
$\mathrm{Rh}-\mathrm{O}(3)$ & $2.040(4)$ & $\mathrm{C}(14)-\mathrm{O}(2)$ & $1.247(7)$ \\
$\mathrm{Rh}-\mathrm{P}(1)$ & $2.267(2)$ & $\mathrm{O}(3)-\mathrm{O}(4)$ & $1.493(5)$ \\
$\mathrm{Rh}-\mathrm{P}(2)$ & $2.336(2)$ & $\mathrm{C}(1)-\mathrm{C}(2)$ & $1.528(8)$ \\
$\mathrm{Rh}-\mathrm{Cl}(1)$ & $2.365(2)$ & $\mathrm{C}(1)-\mathrm{C}(14)$ & $1.497(9)$ \\
$\mathrm{C}(13)-\mathrm{C}(14)$ & $1.475(8)$ & & \\
\multicolumn{5}{c}{$\mathrm{Bond})$} \\
\multicolumn{5}{c}{$\mathrm{O}(3)-\mathrm{Rh}-\mathrm{Cl}(1)$} \\
$\mathrm{O}(2)-\mathrm{Rh}-\mathrm{P}(1)$ & $166.83(12)$ \\
$\mathrm{O}(1)-\mathrm{Rh}-\mathrm{P}(2)$ & $165.80(12)$ \\
$\mathrm{O}(3)-\mathrm{Rh}-\mathrm{O}(1)$ & $82.7(2)$ & $\mathrm{O}(1)-\mathrm{C}(1)-\mathrm{C}(14)$ & $110.1(5)$ \\
$\mathrm{O}(1)-\mathrm{Rh}-\mathrm{O}(2)$ & $77.6(2)$ & $\mathrm{O}(1)-\mathrm{C}(1)-\mathrm{C}(2)$ & $113.1(5)$ \\
$\mathrm{O}(1)-\mathrm{Rh}-\mathrm{P}(1)$ & $88.19(12)$ & $\mathrm{C}(14)-\mathrm{C}(1)-\mathrm{C}(2)$ & $114.8(5)$ \\
$\mathrm{O}(3)-\mathrm{Rh}-\mathrm{P}(2)$ & $89.40(12)$ & $\mathrm{O}(1)-\mathrm{C}(1)-\mathrm{O}(4)$ & $110.5(5)$ \\
$\mathrm{O}(2)-\mathrm{Rh}-\mathrm{P}(2)$ & $94.01(12)$ & $\mathrm{O}(4)-\mathrm{C}(1)-\mathrm{C}(14)$ & $102.6(5)$ \\
$\mathrm{O}(2)-\mathrm{Rh}-\mathrm{Cl}(1)$ & $88.24(12)$ & $\mathrm{O}(4)-\mathrm{C}(1)-\mathrm{C}(2)$ & $105.0(5)$ \\
$\mathrm{P}(2)-\mathrm{Rh}-\mathrm{Cl}(1)$ & $92.93(6)$ & $\mathrm{O}(2)-\mathrm{C}(14)-\mathrm{C}(1)$ & $117.8(6)$ \\
$\mathrm{O}(3)-\mathrm{Rh}-\mathrm{O}(2)$ & $78.7(2)$ & $\mathrm{O}(2)-\mathrm{C}(14)-\mathrm{C}(13)$ & $121.4(6)$ \\
$\mathrm{O}(3)-\mathrm{Rh}-\mathrm{P}(1)$ & $98.76(12)$ & $\mathrm{C}(13)-\mathrm{C}(14)-\mathrm{C}(1)$ & $120.7(6)$ \\
$\mathrm{P}(1)-\mathrm{Rh}-\mathrm{P}(2)$ & $99.94(6)$ & $\mathrm{O}(4)-\mathrm{O}(3)-\mathrm{Rh}$ & $108.6(2)$ \\
$\mathrm{O}(1)-\mathrm{Rh}-\mathrm{Cl}(1)$ & $93.28(12)$ & $\mathrm{C}(1)-\mathrm{O}(4)-\mathrm{O}(3)$ & $106.8(4)$ \\
$\mathrm{P}(1)-\mathrm{Rh}-\mathrm{Cl}(1)$ & $93.60(6)$ &
\end{tabular}

$\mathrm{P}(1)-\mathrm{Rh}-\mathrm{Cl}(1)$

$\mathrm{Rh}-\mathrm{O}(1)$
$\mathrm{Rh}-\mathrm{O}(2)$
$\mathrm{Rh}-\mathrm{N}(1)$
$\mathrm{Rh}-\mathrm{P}(1)$
$\mathrm{Rh}-\mathrm{P}(2)$
$\mathrm{Rh}-\mathrm{Cl}(1)$
$\mathrm{C}(1)-\mathrm{O}(1)$
$\mathrm{C}(1)-\mathrm{C}(2)$

$\left[\mathrm{Rh}\left(\mathrm{PPh}_{3}\right)_{2}\left(\mathrm{Cl}_{4} \mathrm{Cat}\right)\left(\mathrm{CH}_{3} \mathrm{CN}\right) \mathrm{Cl}\right]$ Bond Distances $(\AA)$ 1.995(6) $\quad \mathrm{C}(2)-\mathrm{C}(3)$

2.055(6) $\quad \mathrm{C}(3)-\mathrm{C}(4)$

$2.009(8) \quad \mathrm{C}(4)-\mathrm{C}(5)$

2.349(3) $\quad \mathrm{C}(5)-\mathrm{C}(6)$

$2.328(3) \quad \mathrm{C}(6)-\mathrm{C}(1)$

$2.408(3) \quad \mathrm{C}(6)-\mathrm{O}(2)$

1.344(10) $\quad \mathrm{C}(7)-\mathrm{N}(1)$

$1.384(13)$

$1.398(14)$

$1.403(14)$

$1.399(12)$

$1.418(13)$

$1.333(11)$

$1.375(13)$

$1.117(11)$

Bond Angles (deg)

$\mathrm{O}(1)-\mathrm{Rh}-\mathrm{N}(1) \quad 177.9(3)$

$\mathrm{O}(2)-\mathrm{Rh}-\mathrm{P}(1) \quad 169.7(2)$

$\mathrm{P}(2)-\mathrm{Rh}-\mathrm{Cl}(1) \quad 165.20(10)$

$\mathrm{O}(1)-\mathrm{Rh}-\mathrm{O}(2)$

83.6(3)

$\mathrm{N}(1)-\mathrm{Rh}-\mathrm{P}(1)$

91.4(2)

$\mathrm{O}(1)-\mathrm{Rh}-\mathrm{P}(1)$

90.1(2)

$\mathrm{P}(1)-\mathrm{Rh}-\mathrm{Cl}(1)$

85.30(9)

$\mathrm{O}(1)-\mathrm{Rh}-\mathrm{P}(2)$

93.5(2)

$\mathrm{N}(1)-\mathrm{Rh}-\mathrm{P}(2)$

$\mathrm{O}(1)-\mathrm{Rh}-\mathrm{Cl}(1)$

$89.8(2)$

$\mathrm{P}(2)-\mathrm{Rh}-\mathrm{P}(2)$

(2) $-\mathrm{Rh}-\mathrm{P}(2)$

$79.4(2)$

$\mathrm{N}(1)-\mathrm{Rh}-\mathrm{Cl}(1)$

87.4(2)

$\mathrm{O}(2)-\mathrm{Rh}-\mathrm{Cl}(1)$

$86.6(2)$

$\mathrm{C}(7)-\mathrm{N}(1)-\mathrm{Rh})$

109.10(10)

88.9(2)

177.8(9)

$\mathrm{N}(1)-\mathrm{Rh}-\mathrm{O}(2) \quad 94.8(3) \quad \mathrm{N}(1)-\mathrm{C}(7)-\mathrm{C}(8) \quad 177.1(12)$ 
Table 3. Electronic Spectral and Cyclic Voltammetric Data

\begin{tabular}{|c|c|c|c|}
\hline compd & solvent & $\begin{array}{l}\text { electronic spectral data: } \\
\lambda_{\max }, \mathrm{nm}\left(\epsilon, \mathrm{M}^{-1} \mathrm{~cm}^{-1}\right)\end{array}$ & $\begin{array}{l}\text { cyclic voltammetric data: } \\
\qquad E, \text { V vs SCE }\end{array}$ \\
\hline$\left[\mathrm{Rh}\left(\mathrm{PPh}_{3}\right)_{2}\left(\mathrm{O}_{2}-\mathrm{PSQ}\right) \mathrm{Cl}\right]$ & $\mathrm{CH}_{2} \mathrm{Cl}_{2}$ & 400 (3500), 310 (11 000), 255 (43 000), 250 (42 000), 225 (39 300) & $0.900^{a}-1.00^{b}$ \\
\hline$\left[\mathrm{Rh}\left(\mathrm{PPh}_{3}\right)_{2}\left(\mathrm{Cl}_{4} \mathrm{Cat}\right) \mathrm{Cl}\right]$ & $\mathrm{CH}_{2} \mathrm{Cl}_{2}$ & $\begin{array}{l}700(3800), 470(2200), 380(2000), 280(32500), 250(44400) \\
215(85000)\end{array}$ & $0.85^{c}(300),{ }^{d}-0.90^{b}$ \\
\hline$\left[\mathrm{Rh}\left(\mathrm{PPh}_{3}\right)_{2}\left(\mathrm{Cl}_{4} \mathrm{Cat}\right)\left(\mathrm{CH}_{3} \mathrm{CN}\right) \mathrm{Cl}\right]$ & $\mathrm{CH}_{3} \mathrm{CN}$ & 510 (641), 315 (9800), 250 (30 000), 220 (53 000), 205 (47 000) & $0.65^{c}(60),{ }^{d}-1.04^{b}$ \\
\hline
\end{tabular}

Formation of this $\left[\mathrm{Rh}\left(\mathrm{PPh}_{3}\right)_{2}\left(\mathrm{O}_{2}\right.\right.$-PSQ $\left.) \mathrm{Cl}\right]$ complex may be rationalized as shown in Scheme 1. 9,10-Phenanthrenequinone,

\section{Scheme 1}
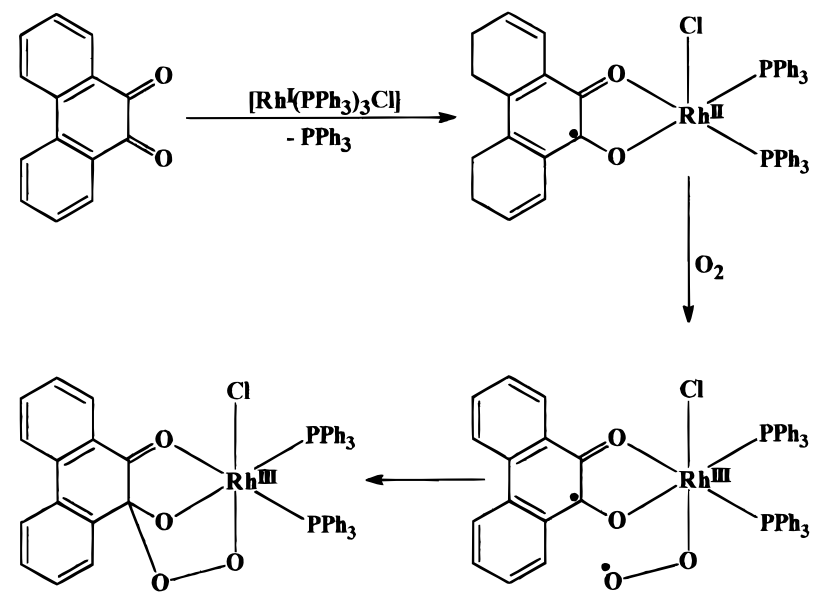

being a mild oxidant, oxidizes rhodium(I) to rhodium(II) and itself gets coordinated in the semiquinone form. This pentacoordinated and unstable $\left[\mathrm{Rh}^{\mathrm{II}}\left(\mathrm{PPh}_{3}\right)_{2}(\mathrm{PSQ}) \mathrm{Cl}\right]$ complex then undergoes further oxidation by aerial oxygen to generate the superoxo complex which is followed by obvious $\mathrm{C}-\mathrm{O}$ bond formation between two close radical centers to afford the [Rh$\left.\left(\mathrm{PPh}_{3}\right)_{2}\left(\mathrm{O}_{2}-\mathrm{PSQ}\right) \mathrm{Cl}\right]$ complex. It may be noted here that there are very few reports of peroxysemiquinone complexes in the literature. ${ }^{19}$ The $\mathrm{Rh}-\mathrm{O}, \mathrm{Rh}-\mathrm{P}$, and $\mathrm{Rh}-\mathrm{Cl}$ distances are quite normal. ${ }^{20}$ The $\mathrm{C} 14-\mathrm{O} 2$ distance indicates that it is a localized double bond, while the $\mathrm{C} 1-\mathrm{O} 1$ and $\mathrm{C} 1-\mathrm{O} 4$ distances are much longer which confirms their single bond character. The $\mathrm{O}-\mathrm{O}$ distance compares well with the $\mathrm{O}-\mathrm{O}$ distances in structurally characterized peroxo complexes. ${ }^{20}$ The $\mathrm{C} 1-\mathrm{C} 2, \mathrm{C} 1-\mathrm{C} 14$, and C14-C13 lengths indicate their single bond character, as expected.

Infrared spectrum of the $\left[\mathrm{Rh}\left(\mathrm{PPh}_{3}\right)_{2}\left(\mathrm{O}_{2}\right.\right.$-PSQ $\left.) \mathrm{Cl}\right]$ complex shows a strong $v(\mathrm{C}=\mathrm{O})$ vibration at $1580 \mathrm{~cm}^{-1}$ and a distinct vibration at $850 \mathrm{~cm}^{-1}$ due to the bridging peroxo fragment. ${ }^{21}$ Strong vibrations are observed at 508, 519, 534, 678, 690, and $740 \mathrm{~cm}^{-1}$, and these may be attributed to the cis- $\mathrm{Rh}\left(\mathrm{PPh}_{3}\right)_{2}$ fragment as similar cis- $\mathrm{M}\left(\mathrm{PPh}_{3}\right)_{2}(\mathrm{M}=\mathrm{Ru}, \mathrm{Os})$ fragments are known to display such vibrations. ${ }^{22-24}$ The $v(\mathrm{Rh}-\mathrm{Cl})$ stretch is observed at $330 \mathrm{~cm}^{-1} .{ }^{25}$ The $\left[\mathrm{Rh}\left(\mathrm{PPh}_{3}\right)_{2}\left(\mathrm{O}_{2}\right.\right.$-PSQ)Cl] complex is diamagnetic, which corresponds to the trivalent state of rhodium (low-spin $\mathrm{d}^{6}, S=0$ ) in this complex. The ${ }^{1} \mathrm{H}$ NMR

(19) Barbaro, P.; Bianchini, C.; Linn, K.; Mealli, C.; Meli, A.; Vizza, F. Inorg. Chim. Acta 1992, 198-200, 31.

(20) Benett, M. J.; Donaldson, P. B. Inorg. Chem. 1977, 99, 1581.

(21) Chaudhuri, M. K.; Ghosh, S. K. Inorg. Chem. 1982, 60, 4020

(22) Bhattacharya, S.; Pierpont, C. G. Inorg. Chem. 1991, 30, 1511.

(23) Bhattacharya, S.; Pierpont, C. G. Inorg. Chem. 1991, 30, 2906.

(24) Pramanik, N. C.; Bhattacharya, S. Transition Met. Chem. 1999, 24, 95.

(25) Deb, A. K.; Goswami, S. J. Chem. Soc., Dalton. Trans. 1989, 1635. spectrum of this complex, recorded in $\mathrm{CDCl}_{3}$ solution, shows a number of overlapping resonances in the aromatic (7.0-8.0 $\mathrm{ppm}$ ) region due to signals from the $\mathrm{O}_{2}$-PSQ ligand as well as the two nonequivalent $\mathrm{PPh}_{3}$ ligands. However, the ${ }^{31} \mathrm{P} \mathrm{NMR}$ spectrum of the same complex shows only two distinct resonances at 43.22 and $43.87 \mathrm{ppm}$ which is in accordance with the observed structure of this complex. The electronic spectrum of $\left[\mathrm{Rh}\left(\mathrm{PPh}_{3}\right)_{2}\left(\mathrm{O}_{2}-\mathrm{PSQ}\right) \mathrm{Cl}\right]$, recorded in dichloromethane solution, shows three very intense absorptions in the UV region together with two intense absorptions in the visible region (Table 3 ). The absorptions in the UV region are assignable to transitions within the ligand orbitals while those in the visible region are probably due to metal-to-ligand charge-transfer transitions. Besides small differences in band positions and intensities, the electronic spectrum of $\left[\mathrm{Rh}\left(\mathrm{PPh}_{3}\right)_{2}\left(\mathrm{O}_{2}-\mathrm{PSQ}\right) \mathrm{Cl}\right]$ in acetonitrile solution is qualitatively similar to that observed in the dichloromethane solution.

To test whether two-electron oxidation at the metal center can be brought about by the quinone ligand alone and thus participation of molecular oxygen in the synthetic reaction (as shown in Scheme 1) can be chemically controlled, a reaction was carried out between 3,4,5,6-tetrachloro-1,2-benzoquinone and $\left[\mathrm{Rh}\left(\mathrm{PPh}_{3}\right)_{3} \mathrm{Cl}\right]$ under identical experimental conditions as before. The product obtained from this reaction was indeed found to be much different. Microanalytical data indicated that the complex molecule contains two $\mathrm{PPh}_{3}$ ligands, one chloride, and the quinone ligand coordinated to rhodium. The infrared spectrum of this complex shows the $v(\mathrm{Rh}-\mathrm{Cl})$ stretch at 325 $\mathrm{cm}^{-1}$ and strong vibrations due to the $\mathrm{Rh}\left(\mathrm{PPh}_{3}\right)_{2}$ fragment within $500-750 \mathrm{~cm}^{-1}$ as before. However the IR spectrum did not show any $v(\mathrm{C}=\mathrm{O})$ or $v(-\mathrm{O}-\mathrm{O}-)$ stretch. This indicates that the quinone ligand is coordinated in the catecholate form. The complex molecule may therefore be represented as $\left[\mathrm{Rh}^{\text {III }}\right.$ $\left.\left(\mathrm{PPh}_{3}\right)_{2}\left(\mathrm{Cl}_{4} \mathrm{Cat}\right) \mathrm{Cl}\right]$. This complex is diamagnetic as expected, and its ${ }^{1} \mathrm{H}$ NMR spectrum in $\mathrm{CDCl}_{3}$ solution shows the aromatic proton resonances of the $\mathrm{PPh}_{3}$ ligands within 7.1-7.5 ppm. The ${ }^{31} \mathrm{P}$ NMR spectrum shows a single sharp resonance at 46.87 ppm, which indicates that the two $\mathrm{PPh}_{3}$ ligands are magnetically equivalent in this complex, and hence there are three possible geometries for this complex molecule, one square pyramidal (3) and two trigonal bipyramidal (4) and (5). Single crystals of

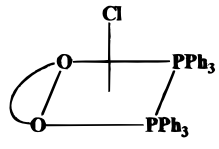

3

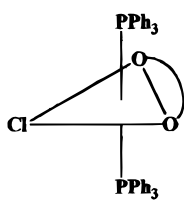

4

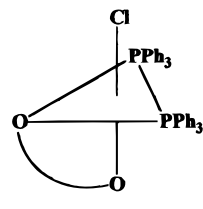

5 this complex could not be grown, and hence, this problem of stereochemistry could not be sorted out. However, in view of the structure of $\left[\mathrm{Rh}\left(\mathrm{PPh}_{3}\right)_{2}\left(\mathrm{O}_{2}-\mathrm{PSQ}\right) \mathrm{Cl}\right]$, the square pyramidal geometry (3) may be assumed for this $\left[\mathrm{Rh}\left(\mathrm{PPh}_{3}\right)_{2}\left(\mathrm{Cl}_{4} \mathrm{Cat}\right) \mathrm{Cl}\right]$ complex. 


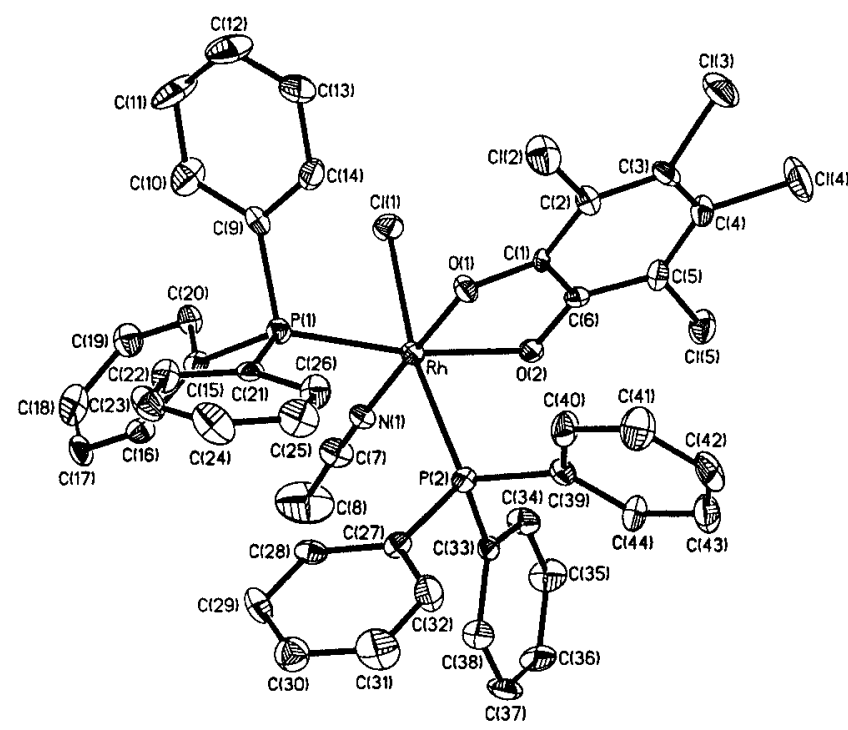

Figure 2. View of the $\left[\mathrm{Rh}\left(\mathrm{PPh}_{3}\right)_{2}\left(\mathrm{Cl}_{4} \mathrm{Cat}\right)\left(\mathrm{CH}_{3} \mathrm{CN}\right) \mathrm{Cl}\right]$ molecule.

The electronic spectrum of $\left[\mathrm{Rh}\left(\mathrm{PPh}_{3}\right)_{2}\left(\mathrm{Cl}_{4} \mathrm{Cat}\right) \mathrm{Cl}\right]$ in dichloromethane solution shows intense metal-to-ligand $\left(\mathrm{Cl}_{4} \mathrm{Cat}\right)$ charge-transfer transitions in the visible region together with usual intense absorptions in the UV region. The spectrum of $\left[\mathrm{Rh}\left(\mathrm{PPh}_{3}\right)_{2}\left(\mathrm{Cl}_{4} \mathrm{Cat}\right) \mathrm{Cl}\right]$ in acetonitrile solution is observed to be noticeably different, and this indicates coordination of the solvent. This was scrutinized further by analyzing the crystalline solid obtained from evaporation of a solution of $\left[\mathrm{Rh}\left(\mathrm{PPh}_{3}\right)_{2}\left(\mathrm{Cl}_{4}\right.\right.$ $\mathrm{Cat}) \mathrm{Cl}$ ] complex in acetonitrile. The new complex was indeed found to contain coordinated acetonitrile and is represented as $\left[\mathrm{Rh}\left(\mathrm{PPh}_{3}\right)_{2}\left(\mathrm{Cl}_{4} \mathrm{Cat}\right)\left(\mathrm{CH}_{3} \mathrm{CN}\right) \mathrm{Cl}\right]$. Formation of this complex has been authenticated by its structure determination by X-ray crystallography. The structure is shown in Figure 2, and selected bond parameters are listed in Table 2. Rhodium is sitting in a distorted octahedral $\mathrm{NO}_{2} \mathrm{P}_{2} \mathrm{Cl}$ coordination sphere with the two $\mathrm{PPh}_{3}$ ligands in cis positions. The $\mathrm{C}-\mathrm{O}$ bond lengths clearly indicate catecholate nature of the $\mathrm{Cl}_{4} \mathrm{Cat}$ ligand. ${ }^{13}$ Acetonitrile is coordinated to rhodium in the usual manner ${ }^{26}$ with slight deviation from linearity around $\mathrm{N}(1)$ and $\mathrm{C}(7)$. This structure determination thus proves that oxidation of $\mathrm{Rh}(\mathrm{I})$ to $\mathrm{Rh}(\mathrm{III})$ has been done solely by the $\mathrm{Cl}_{4} \mathrm{BQ}$ ligand and therefore participation of dioxygen was not necessary.

Comparison of the compositions and geometries of [Rh$\left.\left(\mathrm{PPh}_{3}\right)_{2}\left(\mathrm{Cl}_{4} \mathrm{Cat}\right) \mathrm{Cl}\right]$ and $\left[\mathrm{Rh}\left(\mathrm{PPh}_{3}\right)_{2}\left(\mathrm{Cl}_{4} \mathrm{Cat}\right)\left(\mathrm{CH}_{3} \mathrm{CN}\right) \mathrm{Cl}\right]$ suggests

(26) Pramanik, N. C.; Pramanik, K.; Ghosh, P.; Bhattacharya, S. Polyhedron 1998, 17, 1525 . that removal of acetonitrile from the coordination sphere of [Rh$\left.\left(\mathrm{PPh}_{3}\right)_{2}\left(\mathrm{Cl}_{4} \mathrm{Cat}\right)\left(\mathrm{CH}_{3} \mathrm{CN}\right) \mathrm{Cl}\right]$ should result in formation of the pentacoordinated $\left[\mathrm{Rh}\left(\mathrm{PPh}_{3}\right)_{2}\left(\mathrm{Cl}_{4} \mathrm{Cat}\right) \mathrm{Cl}\right]$ complex associated with a stereochemical change from octahedral to square pyramidal. This was examined by thermal analysis of the [Rh$\left.\left(\mathrm{PPh}_{3}\right)_{2}\left(\mathrm{Cl}_{4} \mathrm{Cat}\right)\left(\mathrm{CH}_{3} \mathrm{CN}\right) \mathrm{Cl}\right]$ complex. At $210^{\circ} \mathrm{C}$ an endothermic change occurs associated with the loss of $\sim 40 \mathrm{~g}$ mass $/ \mathrm{mol}$ of the complex, which points to loss of the coordinated acetonitrile. The product obtained after this heat treatment has indeed been found to be $\left[\mathrm{Rh}\left(\mathrm{PPh}_{3}\right)_{2}\left(\mathrm{Cl}_{4} \mathrm{Cat}\right) \mathrm{Cl}\right]$, identified by microanalysis and spectroscopic properties. This shows that chemical interconversion between $\left[\mathrm{Rh}\left(\mathrm{PPh}_{3}\right)_{2}\left(\mathrm{Cl}{ }_{4} \mathrm{Cat}\right) \mathrm{Cl}\right]$ and $\left[\mathrm{Rh}\left(\mathrm{PPh}_{3}\right)_{2^{-}}\right.$ $\left.\left(\mathrm{Cl}_{4} \mathrm{Cat}\right)\left(\mathrm{CH}_{3} \mathrm{CN}\right) \mathrm{Cl}\right]$ can be performed without any difficulty.

The electronic spectrum of $\left[\mathrm{Rh}\left(\mathrm{PPh}_{3}\right)_{2}\left(\mathrm{Cl}_{4} \mathrm{Cat}\right)\left(\mathrm{CH}_{3} \mathrm{CN}\right) \mathrm{Cl}\right]$ in acetonitrile solution shows rhodium-to-catechol chargetransfer transition in the visible region and usual intense transitions in the UV region (Table 3 ). The ${ }^{1} \mathrm{H}$ NMR spectrum of this diamagnetic $\left[\mathrm{Rh}\left(\mathrm{PPh}_{3}\right)_{2}\left(\mathrm{Cl}_{4} \mathrm{Cat}\right)\left(\mathrm{CH}_{3} \mathrm{CN}\right) \mathrm{Cl}\right]$ complex shows the lack of symmetry in the complex molecule. The aromatic protons of the $\mathrm{PPh}_{3}$ ligands show several resonances within 7.1-7.8 ppm. The methyl signal of coordinated acetonitrile is observed at $1.24 \mathrm{ppm}$. The ${ }^{31} \mathrm{P}$ NMR spectrum shows a relatively broad signal centered at $46.92 \mathrm{ppm}$ due to overlap of the two signals arising from the two $\mathrm{PPh}_{3}$ ligands.

Electron-transfer properties of all three complexes have been studied by cyclic voltammetry. Each complex shows an oxidative response on the positive side of SCE and a reductive response on the negative side (Table 3 ). The reduction may be assigned to rhodium(III)-rhodium(II) reduction, while the oxidation is believed to be ligand $\left(\mathrm{O}_{2}\right.$-PSQ or $\mathrm{Cl}_{4}$ Cat $)$ centered.

Generation of other $\mathrm{Rh}^{\mathrm{II}}-\mathrm{SQ}$ complexes using different types of quinone ligands and their reactivity with molecular oxygen are currently under investigation. Utilization of $\left[\mathrm{Rh}\left(\mathrm{PPh}_{3}\right)_{2}\left(\mathrm{O}_{2}-\right.\right.$ $\mathrm{PSQ}) \mathrm{Cl}$ ] and similar complexes as catalysts to bring about useful oxo-transfer reactions is also being explored.

Acknowledgment. Financial assistance received from the Council of Scientific and Industrial Research, New Delhi [Grant No. 01(1408)/96/EMR-II], is gratefully acknowledged. The authors thank the Third World Academy of Sciences for financial support for the purchase of an electrochemical cell system and the Bose Institute, Calcutta 700054, India, for NMR spectral measurements. Thanks are also due to Professor N. Ray Chaudhuri of the Indian Association for the Cultivation of Science, Calcutta, India, for helping with the thermal analysis. S.D. thanks the CSIR, New Delhi, for her fellowship.

IC990999V 